\title{
Krzysztof Sala
}

Uniwersytet Pedagogiczny

im. Komisji Edukacji Narodowej

w Krakowie

\section{Baza noclegowa jako czynnik rozwoju regionów w Polsce}

\section{The accommodation sector as a factor in the development of regions in Poland}

\section{Streszczenie}

Celem publikacji jest przedstawienie złożoności zjawisk związanych z wpływem bazy noclegowej na politykę regionalną. Artykuł prezentuje znaczenie bazy noclegowej, a w szczególności hotelarskiej, dla rozwoju województw w Polsce. Ukazuje historyczny rozwój bazy noclegowej w kontekście znaczenia na rynku regionalnym. Tłumaczy jej rolę jako istotnego i ważnego elementu wpływającego na współczesną sytuację regionów w naszym kraju, a także jako kluczowej szansy na zmianę bieżącego często niekorzystnego stanu gospodarczego. W publikacji przedstawiono wpływ bazy hotelarskiej na sytuację w miastach i na wsiach. Turystyka oraz powiązane z nią hotelarstwo coraz częściej stają się instrumentem polityki regionalnej, aktywizacji społeczeństw lokalnych oraz budowy podstaw rozwoju gospodarczego. Należy tutaj również dodać wpływ na świadomość społeczną, identyfikację i postawy społeczne, rozwój zrównoważony oraz działania na rzecz podwyższania konkurencyjności i atrakcyjności regionów. W publikacji, oprócz prezentacji analizy danych statystycznych i dostępnych materiałów dotyczących rozwoju bazy noclegowej, oceniono również zachodzące w niej zmiany, a także podjęto próbę prognozy rozwoju bazy noclegowej w Polsce, w obliczu nowej sytuacji gospodarczej. Prognozy, której charakter w dużym stopniu będzie uzależniony od napływu inwestycji zagranicznych, powstawania nowych firm czy opłacalności zaciągania kredytów. Nie bez znaczenia będzie również rozwój sytuacji gospodarczej na świecie i w Polsce, integracja kolejnych krajów z Unią Europejską czy też napływ środków unijnych w ramach regionalnych programów operacyjnych. Na podstawie wyników analiz i studiów prezentowanych w tekście można wysnuć wniosek, że baza noclegowa w kluczowy sposób zmienia rzeczywistość gospodarczą regionów i przyczynia się do poprawy ich sytuacji ekonomicznej. Dotyczy to zarówno obszarów miejskich, jak i obszarów wiejskich, które w większym stopniu różnią od średniego poziomu rozwoju kraju.

\section{Abstract}

The article aims to present the meaning of the accommodation sector, and particularly of hotel management, in the development of provinces in Poland. It presents the historical development of the accommodation sector in the context of its meaning on the regional market. The paper shows the meaning of the accommodation sector as an essential and important element influencing the contemporary situation of regions in our country, and also as a key opportunity to change the current, often disadvantageous economic situation. The paper illustrates the influence of the accommodation sector on the situation in cities and in the countryside. Tourism and its related hotel business are, increasingly more often, becoming an instrument of regional policy, activation of local societies, and the construction of the foundations of economic development. One should also add here the influence on social awareness, identification and social attitudes, sustainable development and activities in the interest of increasing the competitiveness and attractiveness of regions. The publication, presenting 
the data analysis of statistical and accessible materials concerning the development of the accommodation sector, evaluates the changes that have taken place, and also attempts to foresee the future in the face of the new economic situation. Prognoses, the character of which will, to a large degree, be dependent on the influx of foreign investments, the formation of new companies or the profitability of contracting credits. Also of significance will be the development of the economic situation both globally and in Poland, the integration of subsequent countries with the European Union, or the inflow of EU resources within the framework of regional operating programs.

Słowa kluczowe: baza noclegowa; konsumenci; region; rozwój

Keywords: accommodation; consumers; development; region

\section{Wstęp}

Baza noclegowa jest jednym z kluczowych czynników zagospodarowania turystycznego regionu. W jej skład wchodzą różnego rodzaju obiekty noclegowe i urządzenia towarzyszące, pozwalające turystom na przebywanie poza miejscem zamieszkania w warunkach zbliżonych do ich stałych warunków pobytu. Rozwój bazy noclegowej nie pozostaje bez wpływu na gospodarczy i społeczny rozwój regionów. Można tutaj wymienić co najmniej kilka czynników, które mają ścisły związek ze zmianami związanymi z bazą noclegową:

- ożywienie gospodarcze regionu,

- wzrost atrakcyjności inwestycyjnej,

- poprawa infrastruktury,

- zwiększenie liczby miejsc pracy,

- wzrost dochodów z podatków.

Tak jak w przypadku innych dziedzin gospodarki, rozwój bazy noclegowej jest uwarunkowany przez czynniki zewnętrznie i wewnętrzne. Należy tutaj wymienić przede wszystkim wzrost liczby podróży turystycznych i mobilności mieszkańców, które bezpośrednio wpływają na kształtowanie wielkości bazy noclegowej na danym obszarze.

Przedmiot artykuły stanowi charakterystyka bazy noclegowej jako istotnego elementu zagospodarowania regionów w Polsce. Celem publikacji jest przedstawienie bazy noclegowej, w szczególności hotelarskiej, jako istotnego czynnika przyspieszającego modernizację i postęp w rozwoju regionów w Polsce. Tezą, którą postawiono w tekście, jest założenie, że baza noclegowa znacząco zmienia sytuację gospodarczą regionów.

W artykule zaprezentowano najnowsze dane statystyczne, wzbogacone o zebrane już wcześniej informacje, dotyczące możliwie jak najszerszego zakresu przestrzennego. Publikacja powstała na podstawie ogólnodostępnych danych statystycznych, a także literatury i źródeł internetowych. Metodą badawczą, którą zastosowano w tekście, była krytyka piśmiennicza literatury obejmującej poruszaną tematykę. Podejście badawcze uwzględniało dane ilościowe i jakościowe dotyczące bazy noclegowej i jej wpływu na gospodarkę regionów. Narzędzie badawcze stanowiła analiza danych zastanych.

Wybór tematu publikacji wynikał z zainteresowań osobistych autora oraz z faktu ciągłego rozrostu bazy noclegowej i zwiększania liczby hoteli w Polsce na przestrzeni ostatnich kilkunastu lat. Dzieje się tak pomimo zmiennej i niepewnej sytuacji gospodarczej. Taki stan rzeczy nie może być obojętny na obszary, na których dochodzi do takich zjawisk. Dostępna do tej pory literatura nie wyczerpuje tematyki omawianego zagadnienia, albowiem opisuje rozwój regionów pod wpływem całokształtu turystyki (Kandefer) lub wpływ bazy noclegowej tylko na wybrane regiony w Polsce (Świstak, Tul-Krzyszczuk). 


\section{Historyczna rola i tendencje w rozwoju bazy noclegowej na rynku turystycznym}

Rozwój bazy noclegowej i zakładów hotelarskich następował wraz ze wzrostem ruchliwości ludzkiej i z postępem technicznym. Już od zarania dziejów człowiek potrzebował miejsca do spania. Usługi noclegowe należą do podstawowych usług turystycznych (Gaworecki, 2010: 260).

Istnienie bazy noclegowej od zawsze znacząco wpływało na ożywienie i rozwój gospodarczy danego obszaru. Budowane w starożytnej Grecji państwowe pandokia olśniewały przepychem i bogactwem wystroju. Umiejscowione w centrach miast służyły nie tylko jako obiekty hotelarskie, lecz także jako centra wymiany handlowej. W ten sposób przyczyniały się do rozwoju gospodarczego ośrodków miejskich. W państwie rzymskim rozwinięta baza zajazdów, usytuowana wzdłuż sieci utwardzanych dróg, stanowiła ważny element zagospodarowania szlaków handlowych i położonych na ich trasie jednostek osadniczych. Znacznie ułatwiała zagospodarowanie rozległych ziem Imperium Rzymskiego i przyspieszała ich awans cywilizacyjny.

W średniowieczu klasztory miały obowiązek przyjmowania wędrowców, udzielania im noclegu, wyżywienia i podstawowej opieki. Początkowo nakaz ten wypełniano bezpłatnie, z czasem jednak przyjął formę zarobkową. Najgęstszą siecią przyklasztornego zakwaterowania mogła się poszczycić Szwajcaria.

Historia hotelarstwa i bazy noclegowej w Polsce sięga czasów wczesnego średniowiecza i początków formowania się państwowości polskiej. Pierwowzorem dzisiejszych hoteli były hospicja, karczmy wiejskie i gospody miejskie (szynki) (Błądek, Tulibacki, 2003). Pierwsze polskie hospicjum przy kościele św. Michała w Poznaniu datuje się na 1170 r. To od tego momentu możemy mówić o zorganizowanym świadczeniu usług noclegowych w Polsce. Początkowo gospody były miejscem spotkań bogatego mieszczaństwa, z czasem stały się instytucjami życia cechowego. Dogodna lokalizacja na traktach handlowych i przymus propinacyjny przyczyniały się do zwiększania ich dochodów. Gospody były miejscami urzędowania poborców ceł i myta, a także ośrodkami handlu płodami rolnymi i wyrobami rzemieślniczymi. W zasadzie średniowieczne karczmy i gospody w niezmiennej formie przetrwały do końca XVII w. Koniec XVII stulecia wiąże się z powstaniem pierwszego w Polsce hotelu Marywill w Warszawie. Obiekt ten pełnił funkcję nie tylko bazy noclegowej, lecz także centrum handlowego. Wkrótce powstały inne podobne obiekty w innych miastach w Polsce - Hotel Polski, Hotel Pruski, hotel Pod Białym Orłem.

Przełom XIX i XX w. przyniósł zmianę jakości w hotelarstwie. Powstały wówczas hotele wzorowane na arystokratycznych pałacach i rezydencjach. Hotele typu palace (pałacowego) były przeznaczone dla bogatego ziemiaństwa, kupców i finansistów, którzy pragnęli się otaczać zbytkiem typowym dla rodzin arystokratycznych. Takie hotele powstały we wszystkich metropoliach europejskich, m.in.: Ritz w Paryżu, Savoy w Londynie, Europejski w Warszawie, Bristol w Warszawie, Francuski w Krakowie, Ritz w Białymstoku, Pod Orłem w Bydgoszczy oraz Bristol - otwarty w 1901 r. Obowiązujące wówczas reguły hotelarstwa przewidywały oferowanie gościom dużej wygody i szeregu usług. Pojawiły się hotelowe restauracje, kawiarnie, lodziarnie, miejsca do gry w bilard, sklepy, a także pralnie.

Kolejne zmiany w bazie noclegowej przyniósł XX w. Pojawia się wtedy turysta - osoba podróżująca dla przyjemności i satysfakcji oraz w celach poznawczych. Urządzonym z przepychem hotelom przybywa tańszej konkurencji w postaci moteli, pensjonatów, schronisk, domów wycieczkowych, gospodarstw agroturystycznych czy kwater prywatnych. Rynek usług noclegowych uległ głębokiej dywersyfikacji pod względem ilościowym i jakościowym. Starał się sprostać zróżnicowanym gustom - od wymagających, bogatych klientów począwszy, skończywszy na osobach poszukujących najprostszych i najtańszych rozwiązań noclegowych (Sala, 2008). Współczesne hotelarstwo to hotele butikowe, kurortowe, biznesowe czy też spa. 
Z drugiej strony dynamicznie rozwija się agroturystyka, starająca się spełnić oczekiwania najmniej wymagających klientów.

Proces przekształceń i zmian jeszcze się nie skończył. Nadal możemy zaobserwować postęp i rozwój bazy noclegowej, który ma na celu sprostanie wymogom zmieniającego się rynku. Baza noclegowa pozostająca w symbiozie z otoczeniem coraz bardziej wpływa na jego rozwój.

\section{Znaczenie bazy noclegowej w rozwoju regionów w Polsce}

Obecny rozwój hotelarstwa w Polsce to powstawanie zarówno luksusowych hoteli, jak i obiektów niższych kategorii, które w większym stopniu zaspokajają istniejący popyt na miejsca noclegowe. W latach 90. w Polsce opracowano strategię rozwoju turystyki i bazy noclegowej, z którą były związane wielkie plany dotyczące m.in. zmniejszenia bezrobocia, zwiększenia przedsiębiorczości mieszkańców czy promocji regionów. Analizując liczbę obiektów hotelarskich w poszczególnych regionach w Polsce, możemy zauważyć duże zróżnicowanie (tab. 1).

Tab. 1. Liczba obiektów hotelarskich w poszczególnych województwach w latach 2004-2012

\begin{tabular}{|l|r|r|r|r|r|}
\hline \multicolumn{1}{|c|}{ Województwo } & $\mathbf{2 0 0 4}$ & $\mathbf{2 0 0 5}$ & $\mathbf{2 0 0 6}$ & $\mathbf{2 0 0 9}$ & $\mathbf{2 0 1 2}$ \\
\hline lódzkie & 50 & 50 & 52 & 67 & 103 \\
\hline mazowieckie & 117 & 120 & 117 & 171 & 173 \\
\hline małopolskie & 146 & 152 & 158 & 251 & 287 \\
\hline śląskie & 110 & 112 & 112 & 147 & 169 \\
\hline lubelskie & 29 & 30 & 37 & 36 & 71 \\
\hline podkarpackie & 45 & 49 & 54 & 89 & 105 \\
\hline podlaskie & 21 & 22 & 21 & 19 & 28 \\
\hline świętokrzyskie & 29 & 31 & 36 & 59 & 73 \\
\hline lubuskie & 53 & 52 & 54 & 63 & 66 \\
\hline wielkopolskie & 122 & 125 & 131 & 206 & 216 \\
\hline zachodniopomorskie & 57 & 64 & 72 & 90 & 104 \\
\hline dolnośląskie & 150 & 146 & 161 & 205 & 218 \\
\hline opolskie & 26 & 26 & 24 & 29 & 36 \\
\hline kujawsko-pomorskie & 70 & 73 & 78 & 94 & 94 \\
\hline pomorskie & 90 & 94 & 102 & 125 & 170 \\
\hline warmińsko-mazurskie & 80 & 85 & 86 & 89 & 101 \\
\hline suma & 1195 & 1231 & 1295 & 1740 & 2014 \\
\hline
\end{tabular}

Źródło: BDL GUS.

Analizując dane zawarte w tab. 1, można zauważyć, że najbardziej rozwiniętą bazą hotelarską wyróżniają się regiony dolnośląski, małopolski i wielkopolski. Najsłabszy poziom rozwoju hotelarstwa prezentują województwa podlaskie, opolskie i świętokrzyskie. Małopolska jest liderem w zakresie rozwoju infrastruktury hotelowej. W latach 2007-2009 zanotowano tutaj przyrost liczby hoteli pięciogwiazdkowych o ponad 66\%, a trzygwiazdkowych o $30 \%$. Region ten mógł się również poszczycić w 2009 r. wysokim wskaźnikiem: 57,4 miejsc w hotelach na 10 tys. mieszkańców, a także pozycją lidera wśród regionów w 2012 r. 
Podlasie należy do województw o najsłabiej rozwiniętej infrastrukturze hotelowej. W latach 2007-2009 dynamika przyrostu liczby hoteli wyniosła tu niespełna 27\%, zaś wzrost liczby miejsc noclegowych osiągnął niecałe 16\%. Wskaźnik liczby hoteli na 10 tys. mieszkańców wynosił w tym regionie w 2009 r. zaledwie 15,2. Poziom inwestycji ulokował region na 15 miejscu. $\mathrm{Na}$ taki stan rzeczy wpływa wiele czynników. Przede wszystkim należy tu wymienić różnice w atrakcyjności turystycznej, dostępności komunikacyjnej czy nakładach promocyjnych.

Można stwierdzić, że pomimo kryzysu i spadku aktywności gospodarczej liczba obiektów hotelarskich rośnie. Rozwój rynku noclegowego pogłębia również dysproporcje pomiędzy regionami w naszym kraju. Do województw dysponujących największą liczbą obiektów i miejsc noclegowych kierowany jest główny strumień inwestycji, baza noclegowa rozwija się tam w sposób bardziej dynamiczny niż w województwach o niższym nasyceniu miejscami noclegowymi. Do czynników, które w największym stopniu będą wpływać na aktywizację gospodarczą regionów, należy rozwój infrastruktury komunikacyjnej, w tym autostrad i dróg szybkiego ruchu, modernizacja szlaków kolejowych i lotnisk. Regiony zajmujące czołowe miejsca pod względem rozwoju infrastruktury hotelowej to województwa dobrze skomunikowane. Poprawa dostępności komunikacyjnej będzie oznaczała wzrost atrakcyjności inwestycyjnej dla podmiotów zewnętrznych, a tym samym szanse na poprawę sytuacji ekonomicznej w danym regionie. Dotyczy to w szczególności województw ściany wschodniej, w których występuje stosunkowo słaby poziom rozwoju szlaków komunikacyjnych. Inne czynniki, które mogą wpłynąć na poprawę sytuacji, to:

- skuteczniejsza promocja kraju, regionu,

- tworzenie nowych atrakcji i produktów turystycznych,

- wzrost zamożności społeczeństwa.

Tab. 2. Wzrost liczby hoteli w Polsce w latach 2002-2012 w podziale na województwa

\begin{tabular}{|l|c|}
\hline \multicolumn{1}{|c|}{ Województwo } & Różnica między rokiem 2002 a 2012 \\
\hline łódzkie & 45 \\
\hline mazowieckie & 62 \\
\hline małopolskie & 178 \\
\hline śląskie & 95 \\
\hline lubelskie & 33 \\
\hline podkarpackie & 70 \\
\hline podlaskie & 8 \\
\hline świętokrzyskie & 46 \\
\hline lubuskie & 19 \\
\hline wielkopolskie & 112 \\
\hline zachodniopomorskie & 46 \\
\hline dolnośląskie & 66 \\
\hline opolskie & 17 \\
\hline kujawsko-pomorskie & 40 \\
\hline pomorskie & 82 \\
\hline warmińsko-mazurskie & 37 \\
\hline
\end{tabular}

Źródło: opracowanie własne na podstawie BDL GUS. 
Analiza danych zawartych w tab. 2 pozwala stwierdzić, że w żadnym z regionów w Polsce nie zmniejszyła się liczba obiektów hotelarskich. Natomiast największe zmiany zanotowano w regionach małopolskim, wielkopolskim i śląskim.

Baza noclegowa należy do czynników, które w decydujący sposób wpływają na sukces określonego regionu turystycznego. Polski rynek noclegowy należy do najsłabiej rozwiniętych w krajach UE. W 2007 r. na 10 tys. mieszkańców Polski przypadały 44 miejsca noclegowe w hotelach i obiektach podobnych (wg Eurostat). Według szacunków Instytutu Hotelarstwa z lipca 2009, wskaźnik ten wzrósł w ostatnich latach i przekracza obecnie 53 miejsca na 10 tys. mieszkańców. Niezależnie od stopnia nasycenia całego kraju hotelami występują duże dysproporcje między poszczególnymi regionami: najwyższe nasycenie - województwo warmińsko-mazurskie (60,8 miejsca w hotelu na 10 tys. mieszkańców), najniższe nasycenie - województwo lubelskie (11,1 miejsca w hotelu na 10 tys. mieszkańców). Istotnym czynnikiem wpływającym na rozwój gospodarczy regionów w Polsce są miejsca pracy generowane przez bazę noclegową i inne usługi turystyczne (ryc. 1). Wpływa to bowiem bezpośrednio na sytuację materialną społeczeństwa, a także na potencjał gospodarczy danego regionu.

Ryc. 1. Udział pracujących w turystyce w stosunku do zatrudnienia ogółem

$\%$

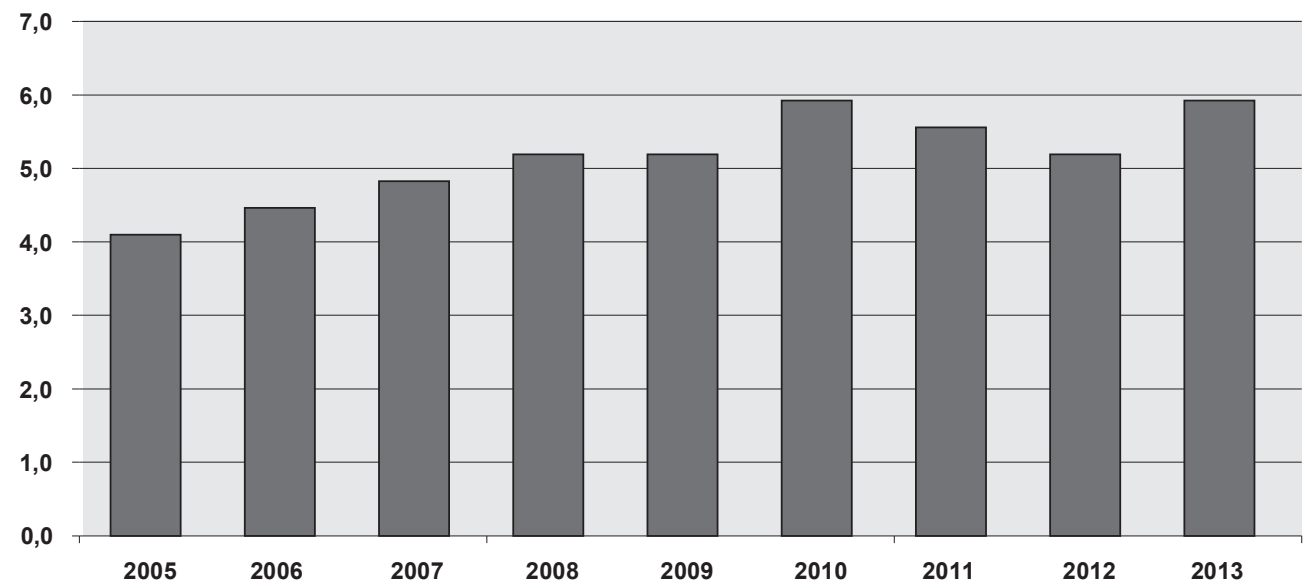

Źródło: opracowanie własne na podstawie danych BDL GUS.

Udział osób pracujących w branży turystycznej - w tym w bazie noclegowej - do ogółu zatrudnionych w poszczególnych regionach nie jest równomierny. Największy odsetek przypada na województwa o wzmożonej aktywności turystycznej, takie jak zachodniopomorskie, małopolskie czy warmińsko-mazurskie. Najniższy odsetek można zaobserwować w województwach wielkopolskim, łódzkim i kujawsko-pomorskim. 


\section{Rola bazy noclegowej w rozwoju i przekształceniach funkcji dużych miast}

Baza noclegowa w dużych miastach odgrywa istotną rolę, przede wszystkim w rozwoju i aktywizacji turystyki biznesowej. Turystyka biznesowa to sektor turystyki, w którym podróże są powiązane $\mathrm{z}$ wykonywanym zawodem lub mają pomóc zatrudnionemu w bardziej efektywnej pracy, a także mogą być nagrodą od pracodawcy za dobrze wykonane zadania (Sidorkiewicz, 2011). Turystykę biznesową cechuje wysoka specjalizacja oraz osiąganie wyższych zysków niż w przypadku pozostałych rodzajów turystyki. Jest ona często utożsamiana z wyjazdami służbowymi, czyli wszystkimi podróżami, których cele są związane z pracą lub interesami zawodowymi podróżującego. W ramach tego rodzaju aktywności możemy wyróżnić:

- indywidualne podróże służbowe,

- turystykę kongresową,

- turystykę targową,

- turystykę motywacyjną,

- szkolenia, kursy.

- turystykę korporacyjną.

Cechą charakterystyczną dla turystyki biznesowej są wyższe o ok. 50\% wydatki turystów w stosunku do wydatków ponoszonych przez osoby podróżujące w celach wypoczynkowych.

W Polsce turystyka biznesowa odgrywa coraz istotniejszą rolę w gospodarce. Przemiany gospodarcze, globalizacja, duża skala inwestycji zagranicznych i wzrost wymiany towarowej stanowią o dynamice podróży służbowych. Niezaprzeczalnym atutem Polski jest również położenie w centralnej Europie na transgranicznych szlakach komunikacyjnych. Cele biznesowe należą do najistotniejszych motywów przyjazdów do Polski (ryc. 2).

Z punktu widzenia rozwoju gospodarczego dużych ośrodków miejskich największe znaczenie ma zbiorowa forma podróży w interesach. $Z$ tego powodu można wskazać na turystykę kongresową i targową jako formy, które w dynamiczny sposób wymuszają zmiany oblicza miast. Wiele ośrodków miejskich, również w Polsce, czerpie ogromne korzyści z tego rodzaju aktywności (Turkowski, 2010). Turyści biznesowi są ważnymi klientami hoteli. Mimo że zamieszkują w hotelach krócej niż turyści podróżujący w celach rekreacyjnych, to wydają na usługi dwukrotnie więcej pieniędzy. Są więc dla hoteli najważniejszymi klientami.

Podróżujący służbowo oczekują od hoteli czegoś więcej niż tylko wygodnych pokoi. Hotele biznesowe i konferencyjne powinny być przede wszystkim wyposażone w dostateczną liczbę sal i pomieszczeń konferencyjnych (Sala, 2008). Do tego należy dodać odpowiednie wyposażenie i obsługę. Pokoje w hotelach biznesowych powinny mieć wydzieloną część do pracy i wyposażenie w zaplecze techniczne: kilka linii telefonicznych, fax, dostęp do internetu. Ponadto goście powinni mieć do dyspozycji bogaty pakiet usług towarzyszących: saunę, basen, kręgielnię, kasyno, rozbudowaną gastronomię. Aby sprostać wymaganiom tak specyficznego rynku, należy zapewnić odpowiedni standard jednostek hotelarskich. Procentowy udział obiektów konferencyjnych w poszczególnych województwach przedstawia tab. 3.

Dane zawarte w tab. 3 wyraźnie wskazują, że regiony mazowiecki, małopolski i dolnośląski są najlepiej przygotowane do organizacji imprez biznesowych. Taki stan rzeczy wynika z dużej koncentracji firm, inwestycji zagranicznych i ważnych przedsiębiorstw w tych regionach. Natomiast najgorsza sytuacja występuje w województwach opolskim, świętokrzyskim i lubuskim. 
Ryc. 2. Udział turystyki biznesowej w ogólnej liczbie przyjazdów do Polski wg województw

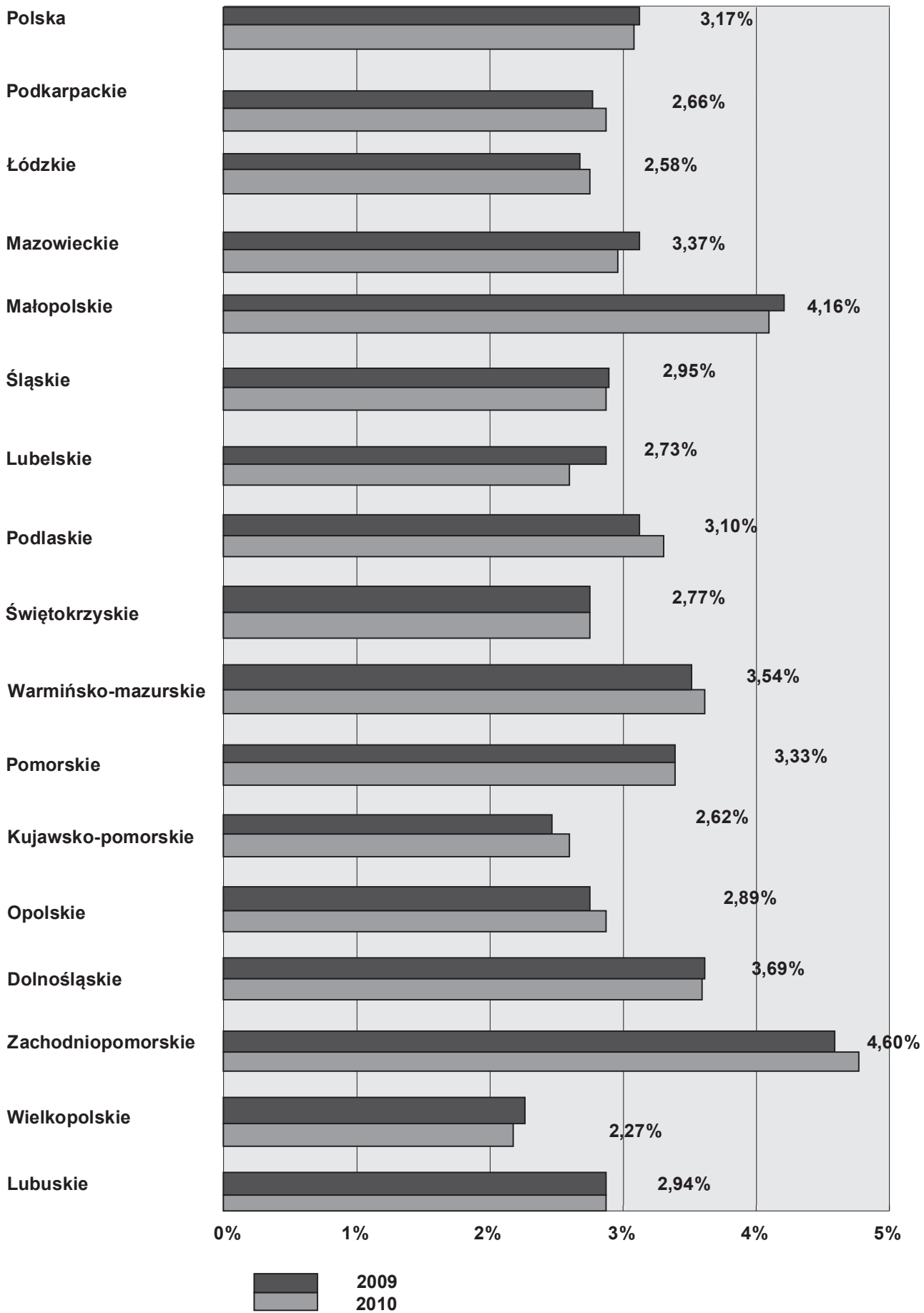

Źródło: opracowanie własne na podstawie danych Instytutu Turystyki, 2013. 
Tab. 3. Obiekty konferencyjne w Polsce wg województw w 2010 r.

\begin{tabular}{|c|c|}
\hline Województwo & Odsetek \\
\hline mazowieckie & $15,8 \%$ \\
\hline małopolskie & $15,0 \%$ \\
\hline dolnośląskie & $9,6 \%$ \\
\hline pomorskie & $9,5 \%$ \\
\hline śląskie & $9,2 \%$ \\
\hline wielkopolskie & $9,2 \%$ \\
\hline warmińsko-mazurskie & $6,6 \%$ \\
\hline zachodniopomorskie & $5,1 \%$ \\
\hline kujawsko-pomorskie & $3,7 \%$ \\
\hline łódzkie & $3,6 \%$ \\
\hline podkarpackie & $2,8 \%$ \\
\hline lubelskie & $2,8 \%$ \\
\hline podlaskie & $2,7 \%$ \\
\hline lubuskie & $1,9 \%$ \\
\hline świętokrzyskie & $1,7 \%$ \\
\hline opolskie & $0,8 \%$ \\
\hline
\end{tabular}

Źródło: K. Cieślikowski, badania własne: prezentacja Turystyka biznesowa jako atrakcyjny produkt w marketingu polskich destynacji.

Jako przykład pozytywnego wpływu turystyki biznesowej na rozwój obszaru miejskiego może służyć Kraków i Małopolska. Do 2000 r. nie było w tym regionie żadnego hotelu pięciogwiazdkowego. Obecnie turysta biznesowy w samym Krakowie ma do dyspozycji ponad 10 hoteli tej kategorii. Do tego należy doliczyć obiekty w innych kategoriach. W Krakowie powstało w sumie 130 hoteli. Miasto ma też najwyższy współczynnik liczby pokoi (107) na 10 tys. mieszkańców. Obecnie w Krakowie budowane są dwa obiekty, które w znaczący sposób przyczynią się do wzbogacenia oferty biznesowej. Będzie to Centrum ICE Kraków oraz Kraków Arena w dzielnicy Czyżyny. Centrum ICE Kraków będzie dysponowało trzema salami konferencyjnymi o łącznej pojemności 3,2 tys. osób. Obiekt będzie umożliwiał organizowanie kongresów, konferencji, koncertów, spektakli i wystaw na niespotykaną dotychczas w mieście skalę. Czyżyńska Kraków Arena będzie dawała możliwość organizacji przede wszystkim imprez sportowych, ale także targowych, kulturalnych i biznesowych z udziałem do 18 tys. osób. Obiekt będzie udostępniał również lokale pod działalność komercyjną. Powyższe inwestycje nie byłyby możliwe, gdyby nie wzrost atrakcyjności Krakowa jako miejsca nie tylko do zwiedzania, lecz także do biznesu.

Podobna sytuacja występuje w Warszawie, która jest największym rynkiem turystyki biznesowej w Polsce. W 2009 r. stolica dysponowała ponad 18,5 tys. miejsc noclegowych w 63 hotelach. Mogła się także pochwalić najwyższym w kraju stopniem wykorzystania pokoi przekraczającym 55\%. Atrakcyjność Warszawy na rynku biznesowym wynika z lokalizacji większości central przedsiębiorstw i firm zagranicznych w Polsce.

Rejonem o znacznym wpływie turystyki biznesowej i obiektów służących temu celowi jest województwo śląskie. Wynika to z kumulacji w tym regionie dużych firm przemysłowych, 
które stanowią naturalny cel podróży służbowych. Katowice mogą się pochwalić znaczącą bazą noclegową: w 2009 r. było tutaj 15 obiektów hotelarskich we wszystkich kategoriach, a także nowymi inwestycjami pobudzającymi rozwój gospodarczy miasta.

Oprócz wymienionych regionów turystyka biznesowa najsilniej wpływa na rozwój gospodarczy w regionach dolnośląskim i wielkopolskim. Zarówno Wrocław, jak i Poznań to miasta o dużym potencjale gospodarczym. Duży napływ inwestycji zagranicznych od początku lat 90. zrodził potrzebę modernizacji i powstania nowych obiektów hotelarskich. Zmieniły one oblicze ekonomiczne tych miast, przyczyniając się dodatkowo do wzrostu atrakcyjności w zakresie organizacji różnego rodzaju imprez biznesowych i nie tylko. Wystarczy dodać, że oba miasta były gospodarzami Euro 2012. Międzynarodowe Targi Poznańskie to wydarzenie biznesowe, którego obsługa ściśle współpracuje z branżą noclegową. Każda inwestycja w obiekty hotelarskie to nowe miejsca pracy, wzrost dochodów budżetowych z tytułu podatków oraz ogólne ożywienie i popularyzacja dla danego regionu. Należy mieć nadzieję na dalszy wzrost udziału inwestycji w gospodarce. W 2009 r. Poznań i Wrocław miały odpowiednio 47 i 37 obiektów hotelarskich. W całej Polsce w 2014 r. było ok. 50 hoteli pięciogwiazdkowych.

\section{Znaczenie gospodarstw agroturystycznych w rozwoju obszarów wiejskich}

Agroturystyka to forma aktywności, którą prowadzi się na terenach rolniczych. Może być połączona z pracą u osoby zapewniającej nocleg. Traktowana jest jako alternatywne do rolnictwa źródło dochodu mieszkańców wsi (Knecht, 2009: 9).

Idea wypoczynku na wsi ma XIX-wieczne korzenie. Istniejący w tamtych czasach ruch regionalistyczny propagował oraz popierał formy lokalnych inicjatyw gospodarczych i kulturalnych. Kariera i rozwój podmiejskich miejscowości zaczęły się w Polsce przed I wojną światową. Pierwszymi masowymi uczestnikami tego rodzaju aktywności były bogatsze warstwy mieszczańskie (Drzewiecki, 1997). Miejscami spędzania czasu na wsi były zarówno domy rolników, jak i pierwsze domy letniskowe. Popularnością cieszyły się wsie położone w otoczeniu aglomeracji miejskich (Świder) oraz te zlokalizowane w dalszych odległościach (Pomiechówek, Skolimów, Zakopane). Duże zasługi w organizowaniu turystyki wiejskiej w Polsce miała założona w 1937 r. Spółdzielnia Turystyczna „Gromada”. To głównie w wyniku jej działalności nastąpił dynamiczny rozwój takich miejscowości wiejskich, jak Krynica, Muszyna, Tleń i Wieluń (Drzewiecki, 2002). W latach 60. popularny w Polsce stał się wypoczynek w miejscowościach wiejskich Warmii i Mazur (Dąbrówno, Stare Juchy). Natomiast w latach 70. nowym terenem ekspansji agroturystycznej zostały Bieszczady (Wetlina, Komańcza). Rozwój turystyki wiejskiej nastąpił tutaj najpóźniej ze względu na zniszczenie i wyludnienie wsi.

Od początku lat 90. agroturystyka znajduje się w fazie dynamicznego rozwoju, zarówno w zakresie ilościowym, jak i jakościowym. Czynnikami odpowiedzialnymi za taki stan rzeczy jest liberalna polityka państwa oraz potrzeby rynkowe gospodarzy i turystów (Czerwińska-Jaśkiewicz, 2013). Na wsiach, zwłaszcza w regionach Mazowsza i Podlasia, istnieją znaczne, niewykorzystane rezerwy zasobów mieszkaniowych, które można wykorzystać jako kwatery agroturystyczne. Agroturystyka to szansa na zatrudnienie oraz czerpanie dochodów z innych usług, np. gastronomicznych, w razie nieopłacalności rozwoju rolnictwa lub przemysłu. Z punktu widzenia nabywcy usług korzystanie z gospodarstw agroturystycznych to sposób na tanie spędzanie wolnego czasu, zwłaszcza podczas kryzysu, a także praktyczna odpowiedź na panujące współcześnie trendy w zakresie ekologii (Sikorska, Kojszczak, 2000). Biorąc pod uwagę szerszy aspekt gospodarczy, rozwój infrastruktury agroturystycznej przyczynia się do:

- podnoszenia standardu i estetyki domów,

- ochrony tradycyjnych i zabytkowych budynków,

- dostarczanie pracy rzemiosłom budowlanym, 
- zapewnienia zbytu produkcji rolnej,

- podtrzymywania lokalnej tradycji i świadomości środowisk wiejskich,

- podnoszenia jakości i standardów życia ludności wiejskiej,

- zapewnienie zakwaterowania na obszarach, na których przemysł hotelowy nie występuje (Sznajder, Przezbórska, 2006).

Znaczny odsetek gospodarstw na wsi jest nastawiony na obsługę turystów zagranicznych, w szczególności niemieckich. Takiemu celowi podporządkowano kosztowne wykończenie wnętrz oraz wyposażenie pokoi w luksusowe meble. Gospodarstwa takie mogą liczyć na uzyskiwanie wyższych dochodów w porównaniu do kwater przeznaczonych wyłącznie dla turystów krajowych.

Do miejscowości wiejskich o wybitnym potencjale agroturystyki należy Bałtów w województwie świętokrzyskim. Na terenie wsi, której liczba mieszkańców nie przekracza 800 osób, istnieje ok. 30 gospodarstw agroturystycznych. Miejscowość ta może być wzorem do naśladowania dla innych wsi w Polsce. Rozwój gospodarczy miejscowości, inwestycje w infrastrukturę i atrakcje przyczyniły się do zwiększenia ruchu turystycznego, którego wielkość wynosi ok. 300 tys. osób rocznie. Bałtów nie poprzestaje na swoich dotychczasowych dokonaniach, lecz nadal inwestuje w nowe atrakcje. Przyczynia się to nie tylko do zawodowej aktywizacji mieszkańców, lecz także do podtrzymywania miejscowych tradycje w rzemiośle, pszczelarstwie i produkcji rolnej.

Pomimo niezaprzeczalnych zalet agroturystyki dla gospodarki, rozwój gospodarstw agroturystycznych w Polsce jest nierównomierny. Polska jest krajem bardzo zróżnicowanym pod względem umiejscowienia liczby takich gospodarstw w poszczególnych regionach. Prekursorami agroturystyki w Polsce były przede wszystkim województwa północnej i południowej części kraju i faktycznie to one przodują w ogólnej statystyce liczby gospodarstw agroturystycznych (tab. 4).

Tab. 4. Liczba gospodarstw agroturystycznych w Polsce wg województw w latach 2007-2011

\begin{tabular}{|l|r|r|r|}
\hline \multicolumn{1}{|c|}{ Województwo } & $\mathbf{2 0 0 7}$ & $\mathbf{2 0 1 0}$ & $\mathbf{2 0 1 1}$ \\
\hline dolnośląskie & 592 & 603 & 638 \\
\hline kujawsko-pomorskie & 333 & 465 & 256 \\
\hline lubelskie & 408 & 476 & 430 \\
\hline lubuskie & 164 & 268 & 95 \\
\hline łódzkie & 167 & 254 & 180 \\
\hline małopolskie & 1590 & 1687 & 1344 \\
\hline mazowieckie & 378 & 460 & 360 \\
\hline opolskie & 112 & 130 & 110 \\
\hline podkarpackie & 1074 & 1298 & 989 \\
\hline podlaskie & 629 & 615 & 609 \\
\hline pomorskie & 770 & 777 & 622 \\
\hline śląskie & 384 & 392 & 384 \\
\hline świętokrzyskie & 355 & 326 & 291 \\
\hline warmińsko-mazurskie & 869 & 1154 & 743 \\
\hline wielkopolskie & 474 & 559 & 418 \\
\hline zachodniopomorskie & 491 & 718 & 383 \\
\hline
\end{tabular}

Źródło: opracowanie własne wg danych GUS. 
Dane wymienione w tab. 4, dotyczące obiektów agroturystycznych, szczegółowo obrazują ich rozłożenie w poszczególnych województwach. Cała baza gospodarstw agroturystycznych liczyła w 2007 r. 8790 obiektów, natomiast w 2010 i 2011 r. odpowiednio 10182 i 7852 obiekty. Największe nasycenie obiektami noclegowymi występuje w województwach małopolskim, podkarpackim i warmińsko-mazurskim, najmniejsze zaś w regionach opolskim, łódzkim i lubuskim.

Powodem nierównomiernego rozwoju agroturystyki w regionach jest przede wszystkim:

- zróżnicowanie przyrodnicze kraju,

- nierównomierność ekonomiczna regionów,

- przeszłość historyczna,

- położenie geograficzne (odległość od dróg i źródeł komunikacji).

W 2010 r., który był wyjątkowy dla agroturystyki, usługi agroturystyczne świadczyło w Polsce ponad 10 tys. gospodarstw, które oferowały 51 tys. miejsc. Największa liczba gospodarstw agroturystycznych występowała w województwie małopolskim: 1687. Ministerstwo Rolnictwa przewiduje, że w 2015 r. gospodarstw agroturystycznych będzie w Polsce ponad 10 tys., a turystycznych na wsi $-7,5$ tys.

\section{Podsumowanie}

Rozwój bazy noclegowej, w tym również zakładów hotelarskich, w znacznym stopniu przyczynia się do modernizacji gospodarczej regionów w Polsce. Należy tu wspomnieć przede wszystkim o nowych, cennych miejscach pracy, które dodatkowo - oprócz samych obiektów dostarczają dochodów podatkowych. Baza noclegowa wpływa na poprawę infrastruktury turystycznej, stanowiąc zachętę dla potencjalnych turystów w zakresie spędzania wolnego czasu, zaś firmy przyciągając w zakresie turystyki biznesowej. Nie bez znaczenia jest również jej rola w tworzenia nowych produktów i atrakcji turystycznych.

Współdziałanie podmiotów gospodarczych, władz samorządowych i operatorów bazy noclegowej może się w przyszłości przyczynić do jeszcze wydajniejszej restrukturyzacji regionów. Chodzi tutaj przede wszystkim o koordynację działań, przyciąganie inwestycji zagranicznych i powstawanie nowych firm.

\section{Literatura \\ References}

Błądek, Z., Tulibacki, T. (2003). Dzieje krajowego hotelarstwa: od zajazdu do współczesności: fakty, obiekty, ludzie. Warszawa: Wydawnictwo Albus.

Czerwińska-Jaskiewicz, M. (2013). Marketing w agroturystyce. Warszawa: Difin.

Drzewiecki, M. (1997). Agroturystyka. Bydgoszcz: Instytut wydawniczy „Świadectwo”.

Drzewiecki, M. (2002). Podstawy agroturystyki. Bydgoszcz: Wydawnictwo OPO.

Gaworecki, W. (2010). Turystyka. Warszawa: Wydawnictwo PWE.

Knecht, D. (2009). Agroturystyka w agrobiznesie. Warszawa: C.H. Beck.

Sala, J. (2008). Formy wspótczesnego hotelarstwa. Kraków: Wydawnictwo Uniwersytet Ekonomiczny Kraków.

Sidorkiewicz, M. (2011). Turystyka biznesowa. Warszawa: Difin.

Sikorska, G., Kojszczak, W. (2000). Kwatera agroturystyczna. Warszawa: Wydawnictwo Polska Fundacja Promocji i Rozwoju Małych i Średnich Przedsiębiorstw. 
Sznajder, M., Przezbórska, L. (2006). Agroturystyka. Warszawa: PWE.

Turkowski, M. (2010). Marketing ustug hotelarskich. Warszawa: PWE.

Marcinkiewicz, C. (2013). Rozwój i stan polskiej agroturystyki. Sosnowiec: Oficyna Wydawnicza „Humanitas".

Zawada, A., Rozwój hotelarstwa na ziemiach polskich.

Ustawa z dnia 29.08.1997 r. o ustugach turystycznych. Dz. U. z 2001 r. nr 55, poz. 578.

Raport końcowy dla badania ewaluacyjnego pn. ,,Wplyw usług turystycznych na rozwój gospodarczy regionu".

Krzysztof Sala, absolwent Międzynarodowych Stosunków Gospodarczych (specjalność Studia Europejskie) na Uniwersytecie Ekonomicznym w Krakowie (studia magisterskie), zakończonych dyplomem na podstawie pracy Realizacja polityki ekorozwoju w krajach skandynawskich, podyplomowych studiów w zakresie zarządzania jakością i ochroną środowiska w Wyższej Szkole Zarządzania i Bankowości w Krakowie oraz Kolegium Zarządzania i Finansów Szkoły Głównej Handlowej w Warszawie (zakończone uzyskaniem tytułu doktora nauk ekonomicznych na podstawie rozprawy Nowe rodzaje turystyki jako przejaw postmodernizmu zachowań konsumenckich w Polsce). Autor ma wieloletnie doświadczenie w praktyce gospodarczej na różnych stanowiskach zawodowych, w tym menedżerskich, oraz doświadczenie w pracy naukowo-dydaktycznej zdobyte na uczeniach publicznych i prywatnych. Działa jako trener w szkoleniach finansowanych z UE w ramach programu Kapitał Ludzki z zakresu szeroko rozumianej turystyki i zarządzania. Do głównych obszarów zainteresowań autora należą polityka gospodarcza i turystyczna Polski oraz UE, przedsiębiorczość w sektorze małych i średnich firm oraz zarządzanie strategiczne.

Krzysztof Sala, The graduate of International Economic relations at university to Economic in Cracow (Master's studies) finished with the diploma on the basis the work ,, the Realization of the policy sustainable development in countries of Scandinavian", postgraduate studies within the range quality managements and with the environmental protection in the Higher School of the Management and the Banking in Cracow and the College of the Management and Finance of the Main Commercial School in Warsaw, finished with the obtainment of the title of the doctor of economic sciences on the basis trials , New kinds of the tourism as the indication post-modernism of behaviours of consumer in Poland". Long experience in effect economic on different professional positions, in this positions of manager. The experience on the job scientific-didactic gained on teachings public and private. The participation as the coach in trainings financed with EU within the framework of the program ,, The Human Capital" from the range concerning of the widely understood tourism and the management. To main areas of interests numbers the economic policy and tourist of Poland and the European Union, the enterprise in the sector of small and average firms and the strategic management.

Adres/Address: Uniwersytet Pedagogiczny im. Komisji Edukacji Narodowej w Krakowie ul. Podchorążych 2 30-084 Kraków, Polska e-mail: krzysztofsal@onet.pl 